\title{
O terror renegado: a retratação pública de integrantes de organizações de resistência à ditadura civil-militar no Brasil, 1970-1975.
}

\author{
Alessandra Gasparotto \\ Rio de Janeiro: Arquivo Nacional, 2012. 276 p.
}

O livro é resultado de uma adaptação da dissertação de mestrado de Alessandra Gasparotto, agraciada com o Prêmio de Pesquisa Memórias Reveladas 2010. Portanto, a obra cumpre com o prérequisito de reunir informações relevantes sobre os fatos da história política recente no país a partir de meticulosa pesquisa.

O tema desenvolvido é o dos "arrependimentos" durante a ditadura civil-miliar no Brasil, em que jovens militantes de esquerda foram apresentados aos veículos de comunicação entre 1970 e 1975, renegando suas atividades na luta-armada e oposição ao regime imposto em 1964. Como apurado no livro, "as retratações eram apresentadas na forma de manifestações públicas, entrevistas coletivas, cartas escritas "de próprio punho" e aparições em programas de televisão, além de declarações de arrependimento atribuídas aos militantes por autoridades policiais e militares". A autora coloca os termos "arrependidos" ou "arrependimento" sempre em itálico, pois considera que foram construídos pelo regime autoritário e pela imprensa da época.

Através de 42 casos referidos no livro, fica evidente que o período de maior incidência desses casos deu-se entre 1970 e 1971, porém o artifício estendeu-se de forma esporádica até 1975. A estratégia do regime foi a de apresentar uma mudança radical no posicionamento e no sentido das ações de antigos militantes que lutaram conta ele de armas na mão. Uma vez "arrependidos", passavam a defensores do regime ao qual combateram. Essas retratações eram tidas como ações individuais, de militantes que se arrependeram da luta por aquisição de consciência de seus erros, foram exploradas com o objetivo apontar a fraqueza moral da esquerda e, principalmente, da luta armada.

Apresentados como "terroristas arrependidos", também chamados na época de "desbundados" os militantes tiveram suas vidas sujeitadas à exposição, ganhando muito destaque na mídia nacional. Em alguns casos os protagonistas nunca foram perdoados pela suposta delação ou abandono da causa. Seus atos repercutiram "nas celas dos presídios, no isolamento da clandestinidade ou do exílio, foram recebidos como traição", observa a autora. O tema nebuloso da traição e do arrependimento é tratado de forma madura, sem explicações simplistas e sem julgamentos de valores precipitados.

Preocupada em contextualizar de forma criteriosa e não repetir a desqualificação a qual foram submetidos por longos anos os "arrependidos", a autora transita pela bibliografia do tema ditadura civilmilitar com desenvoltura e naturalidade, dando assim um sentido acurado na análise de suas fontes primárias que são diversas e muito qualificadas: jornais, revistas, vídeos feitos para televisão, entrevistas 
pela internet, entrevistas com os "arrependidos" e familiares. Dessa maneira, Gasparotto dá voz as suas fontes, mas coteja suas posições com outros dados e caminhos de forma equilibrada, fazendo um balanço contextualizado e jamais anacrônico ou abusivo.

Merece destaque no livro, além de toda a construção teórico-metodológica clara, a abordagem muito bem articulada na reconstrução dos passos do primeiro grupo de "arrependidos" tornado público em 22/5/1970 no Rio Grande do Sul e veiculado com destaque pela televisão e nas capas de três dos principais jornais de Porto Alegre. Mobilizados por Rômulo Fontes, um grupo de cinco jovens chegou a tecer elogios ao governo do presidente Médici e sua realizações. Essa retratação serviu como pedra basilar na construção de uma estratégia de retratações. Foi de fato uma manifestação arquitetada pelos militantes "arrependidos", porém o episódio espontâneo deu o tom para uma série de outros "arrependimentos", ora negociados com contrapartidas de redução de penas ou liberdade, ora impostos a partir de brutal tortura. Também deu margem para diversos convites ao arrependimento e, ainda, falsificação ou alegação de arrependimentos. Então, se houve um movimento espontâneo, ele foi logo ampliado e transformado em ação psicológica para atingir a população, seus desdobramentos contaram com o terrorismo de Estado como meio de convencimento para os reticentes.

Pouco depois do primeiro caso de arrependimento, ganhou notoriedade o caso de Massafumi Yoshinaga de 21 anos, cuja entrevista foi exibida na TV Tupi de São Paulo, no Telejornal Ultra-Notícias do Dia, também foi capa da Revista Veja. Yoshinaga teria sido inclusive referido em discurso do próprio Presidente segundo a Folha de São Paulo em 4 de julho de 1970, e sua manchete "Médici indica o caminho da reconciliação". O teor da matéria dava voz ao Presidente da República: "afirmou que a política nacionalista de desenvolvimento é o caminho para vencer o terrorismo e reconciliar o país, unindo a todos no esforço para a construção de um futuro promissor". Médici ainda teria citado "o caso do ex-terrorista Massafumi Yoshinaga, que se entregou às autoridades em São Paulo, impressionado pelas recentes iniciativas do Governo". Anos mais tarde, sem conseguir estabilidade emocional o jovem Yoshinaga suicidou-se.

Ainda no campo dos casos célebres, a autora dedica uma análise considerável a Celso Lungaretti. Foi tratado de forma muito dura, durante muitos anos por antigos militantes da esquerda que 0 responsabilizavam, ao que tudo indica injustamente, pela delação de um campo de treinamento da VPR. Ao ser apresentado na televisão, Lungaretti havia sido terrivelmente torturado.

"Foi assim que, na noite do dia 9 de julho de 1970, durante a exibição do Jornal Nacional, os telespectadores da TV Globo que esperavam por mais um capítulo da novela Irmãos Coragem, grande sucesso da época, viram-se surpreendidos pela aparição de Lungaretti - um jovem franzino, de 19 anos e aparência abatida, que renegou sua militância política, negou a tortura nos porões do regime, fez um apelo à juventude para que não ingressasse na luta armada e chegou até mesmo a elogiar algumas obras do Presidente Médici" (Gasparotto, 76-77).

Os anos do governo Médici atestam a face mais dura do regime, mas também revelam a mídia em estreita colaboração com o regime na desqualificação de seus opositores. A televisão foi vista como veículo apropriado para atingir o ambiente psicossocial dos grandes centros urbanos, sua utilização foi priorizada por uma ótica de comunicação capaz de mobilizar e sensibilizar a opinião pública ao mesmo tempo em que ela própria, a TV, se valia do tema do "terrorismo arrependido" para e aumentar os índices de audiência.

Ao longo de seu trabalho Alessandra Gasparotto não somente localiza, data, organiza e expõe de forma consistente como foram explorados na época através da televisão e das páginas de jornal as 
retratações públicas dos ditos "arrependidos". Na verdade, ela investiga, dá voz e valoriza a subjetividade dos envolvidos, interpreta resgatando memórias e construindo a história como deve ser; rica e plural. A construção do objeto de sua pesquisa é minuciosamente desenvolvida, sem que isso prejudique a narrativa e a compreensão do leitor, seu rigor não é rigidez, mas compromisso com os personagens, com o contexto, com a memória e com a história, buscado na fluidez de sua escrita e nos filtros de diferentes prismas e fontes. Livro essencial para quem estuda a história do período da ditadura Civil-militar, livro essencial para a memória do Brasil.

Nilo Andé Piana der Castro Colégio de Aplicação da Universidade Federal do Rio Grande do Sul 